\title{
Kewirausahaan dan Panggilan Kristen: Sebuah Pendekatan Interpretatif- Dialogis, Sosio-Historis dan Teologis
}

Suwarto Adi

Fakultas Theologia, Univeritas Kristen Satyta Wacana, Salatiga, Indonesia suwarto@uksw.edu

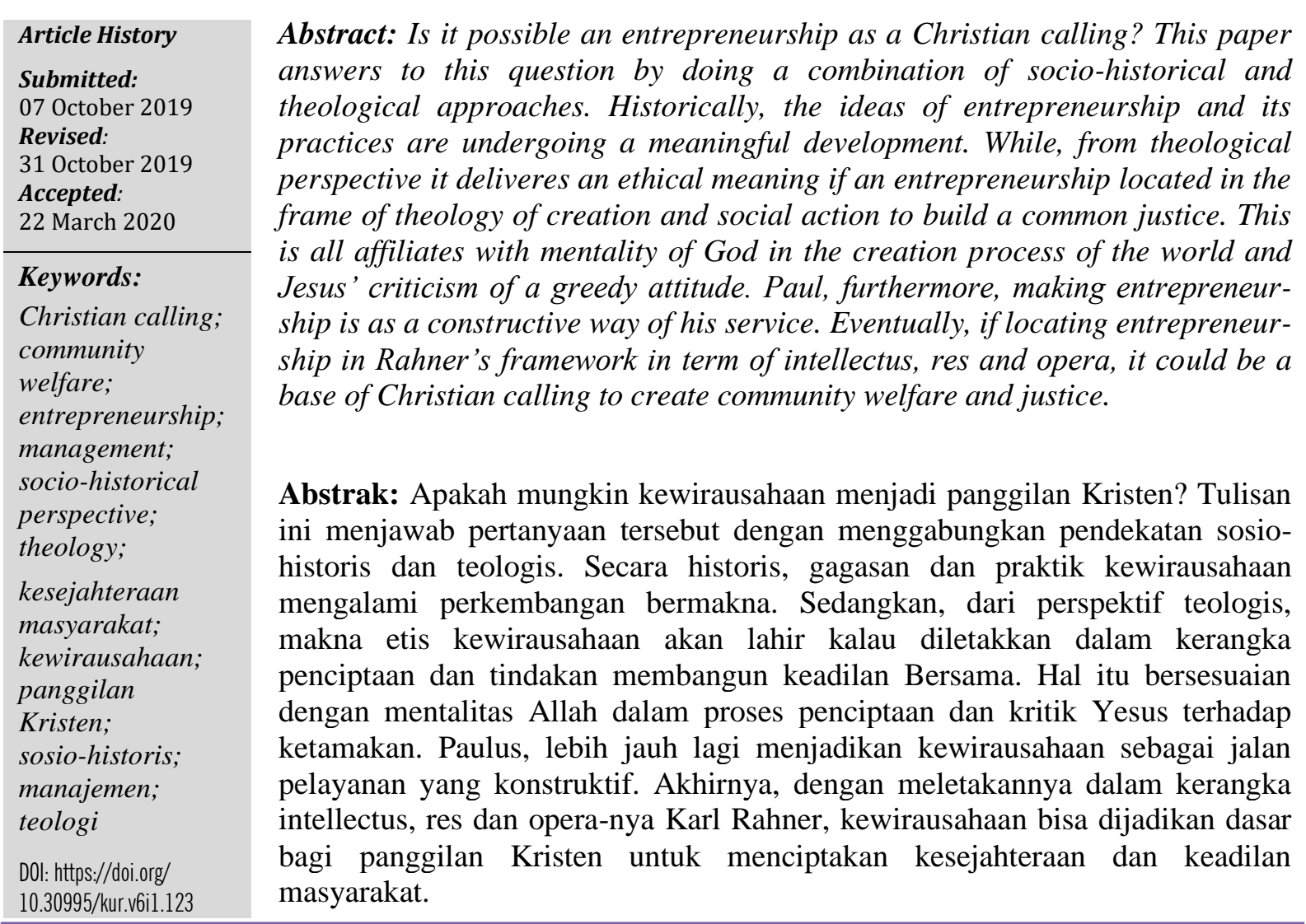

\section{Pendahuluan}

Peran kewirausahaan pada masa kini secara umum dinilai penting. Namun, juga diakui bahwa kewirausahaan tidak selalu dipandang positif. Bahkan, dalam jangka yang panjang hal itu telah dinilai sangat negatif. Istilah bisnis-untuk seterusnya kata bisnis dan kewirausahaan akan digunakan secara bersama maupun bergantian untuk menunjuk makna yang sama-baik secara sosial-budaya dan politik, senantiasa dikaitkan dengan hal yang kurang menyenangkan: suap, kolusi, serakah, egois, dan seterusnya. ${ }^{1}$

Telaah tentang kewirausahaan sendiri relatif baru, dan sebagai kajian akademis, boleh dibilang, belum banyak penelitian skala luas di tingkat universitas. Hal itu terjadi karena kajian kewirausahaan disalahmengerti sekadar sebagai upaya membangun bisnis guna menda-

\footnotetext{
${ }^{1}$ Realino, Penguasa Ekonomi dan Siasat Pengusaha Tionghoa (Yogyakarta, Kanisius dan Lembaga Studi Realino, 1996).
} 
patkan untung. Karena itu, untuk jangka waktu lama, kajian kewirausahaan jatuh menjadi kajian teknis-praktis, dan tidak mengaitkannya dengan pengembangan pemikiran yang teoritik. Tulisan ini berusaha memaparkan kewirausahaan dari perspektif historis, sosiologis dan biblis, dan melanjutkan-nya apakah bisa hal itu dijelaskan sebagai bagian dari panggilan Kristen, khususnya ber-kaitan dengan kerja.

\section{Metode Penelitian}

Tulisan ini merupakan upaya mengungkapkan kewirausahaan dengan pendekatan interpretatif. Beberapa dokumen atau teks yang hendak ditafsir berasal dari berbagai sumber, baik dokumen sejarah, dan/atau bagian Alkitab sebagai dokumen dasar. Tafsir terhadap teks-teks sejarah dilakukan dengan pendekatan sosio-historis. Artinya, teks-teks yang ada diuraikan konteks sosiologisnya, dan dari situ baru dilakukan penafsiran atasnya. Setelah itu, bagian Alkitab ditempuh dengan cara yang sama.

Berdasar cara kerja itu, dapat ditelusuri secara kritis konsep dan perkembangan makna kewirausahaan. Mulai dari pendekatan sejarah, kemudian disusul dengan bagaimana Kitab Suci memandang hal ini (dengan pendekatan yang apresiatif). Setelah itu, dilanjutkan dengan dialog atau peninjauan dari kedua segi: sosio-hitoris dan teologis. Diharapkan melalui tulisan ini kita bisa melihat kewirausahaan secara seimbang, dan bisa menggunakannya untuk mendukung kegiatan sosial atau misi gereja di masyarakat.

\section{Kewirausahaan: Konsep dan Pendekatannya}

Sharon Alvarez ${ }^{2}$ dalam bagian pendahuluan bukunya membuat peta penelitian tentang kewirausahaan. Banyak studi yang lebih menekankan pada individu dan lahirnya kesempatan, sehingga studi itu terasa kurang mewakili perkembangan gagasan kewirausahaan itu sendiri. Karena itu, pendekatan yang lebih luas dan interdisipliner menjadi kebutuhan penting sekarang. Berdasarkan pemikiran dari berbagai sumber, peta penelitian kewirausahaan ke depan bisa digolongkan ke dalam empat ranah. Pertama, kajian yang mengaitkan wira usaha dengan kapitalisasi dan pertumbuhan yang tinggi; kajian ini hendak menguji bahwa kapitalisasi tidak secara otomatis mempengaruhi pertumbuhan; kajian ini terkait erat dengan persoalan manajerial, baik modal dan tenaga kerja. Kedua, berkaitan dengan inovasi, seperti pemikiran Schumpeter bahwa seorang yang inovatif bisa menggerakan lahirnya gagasan baru yang mewujud dengan dukungan organisasi; hal ini tidak terlepas dari fungsi kepemimpinan. Ketiga, menekankan pada "pemanfaatan peluang"; kewirausahaan bisa dilihat dari kemampuan seseorang membaca peluang dan memanfaatkannya; aspek ini berhubungan dengan perhitungan, strategi dan visi seorang wira usaha. Terakhir, berkaitan dengan apa yang dilakukan seorang wira usaha berkenaan dengan penciptaan sebuah organisasi; melalui organisasi bisa dilihat kemampuannya melakukan dengan fungsi klasik wira usaha: inovasi dalam konteks hidupnya.

Kalau bisa diringkas, kajian tentang wira usaha dan kewirausahaan, paling sedikit mengandung empat hal yang menjadi tema utama dalam dunia akademik dewasa ini, yaitu, kemampuan teknis (technical skill), kepemimpinan yang inovatif, visi dan strategi yang optimistis, dan terakhir adalah semua itu mesti diwujudkan dalam sebuah organisasi yang

\footnotetext{
${ }^{2}$ Sharon Alvarez, Rajshree Agarwal, dan Olav Sorenson, Handbook of Entrepreneurship Research: Interdisciplinary Perspectives (New York, Springer, 2005), 1-5.
} 
menjamin keberlanjutan usaha yang telah dirintisnya, baik berupa penciptaan organisasi baru atau pengembangan yang sudah ada menjadi lebih baik dan berkelanjutan. Sehingga, kewirausahaan tidak sekadar berkaitan dengan penciptaan keuntungan ekonomis, tetapi mencakup bidang kehidupan lain yang bertujuan untuk penciptaan kehidupan yang lebih baik, bagi diri sendiri dan masyarakatnya. ${ }^{3}$

Dengan memperhitungkan konsep dan batasan seperti itu, kewirausahaan bukan hanya menjadi wilayah kajian ekonomi saja, tetapi juga terbuka untuk kajian sosiologi dan teologi, termasuk di dalamnya psikologi. ${ }^{4}$ Untuk kajian sosiologi, aspek organisasi menjadi hal yang cukup penting, sebab melalui organisasi, sebuah tindakan memperoleh konteks analisisnya. Dalam kata lain, organisasi menjadi unit analisis kewirausahaan, di mana melalui itu, orang dengan segala tindakannya bisa dilihat secara akademik. Sementara, untuk kajian teologis, aspek karakter dan kepribadian juga bisa dianalisis, seperti sikap dan keberanian pengambilan keputusan apakah didasarkan pada nilai-nilai tertentu, atau pada kebiasaan hidup yang telah membentuknya.

Ringkasnya, konsep kewirausahaan yang dikembangkan dalam tulisan ini merupakan konsep eklektik yang memungkinkan dilakukan telaah sosio-teologis. Sehingga, melalui itu nantinya bisa dirumuskan bahwa kewirausahaan merupakan salah satu tugas dan panggilan Kristen. Namun, sebelum sampai pada rumusan tentang kewirausahaan dan kaitanya dengan panggilan Kristen, pada bagian di bawah akan dilakukan pelacakan sosio-historis tentang semangat kewirausahaan, baik di Jawa maupun Eropa.

\section{Pembahasan}

\section{Perkembangan gagasan dan praktik kewirausahaan: pendekatan sosio-historis}

Wira usaha atau kewirausahaan dalam jangka cukup panjang telah dinilai sebagai pekerjaan yang kurang terhormat. Di Eropa atau di Jawa (dan Indonesia secara umum), hal ini dikaitkan dengan sikap-sikap yang rendah, culas, dan bernada mengejek, walau secara ekonomi pelakunya mempunyai kekayaan yang cukup dan bahkan lebih di antara para anggota masyarakat lainnya, termasuk di antara para bangsawan. ${ }^{5}$

Kewirausahaan di Jawa sejak lama dilekatkan kepada kelompok Cina/Tionghoa dengan sebutan "Cina Mindring”, "Cina Klontong”, "Cina Mata duitan". ${ }^{6}$ Citra itu dipelihara (secara politik) sangat lama, sehingga hanya kelompok Tionghoa yang seolah-olah memang "hanya bisa berdagang”. Karena kekayaannya yang seringkali mencolok, lalu dibangun stereotype bahwa semua itu dilakukan dengan cara-cara yang culas (cari untung banyak), dan bahkan seringkali dikaitkan dengan dunia "gelap" dan magis (pesugihan). Berdagang dengan tidak wajar adalah jelek, dan itulah pekerjaan para pelaku wira usaha.

\footnotetext{
${ }^{3}$ Suwarto Adi, "Religious Entrepreneurship: Christianity and Social Transformation in Contemporary Indonesia", dalam Exchange Vol. 46 (4), 2017, h. 328-349.

${ }^{4}$ Lihat: Alvares, Handbook., h. 3-5.

${ }^{5}$ Lihat: Koentjaraningrat, Javanese Culture (Singapore, Oxford University Press, 1990); C. M. Praag, "Some Classis Views on Entrepreneurship", dalam De Economist, Vol. 147, (3), 1999, h. 311-335; juga, Nakamura, The Crescent Arises over the Banyan Tree: A Study of the Muhammadiyah Movement in Central Javanese Town, $c$. 1910s-2010 (Singapore: ISEAS, 2012).

${ }^{6}$ Kwartanada, "Minoritas Tionghoa dan Fasisme Jepang: Jawa, 1942-1945”, dalam Realino, Penguasa Ekonomi dan Siasat Pengusaha Tionghoa (Yogyakarta, Kanisius dan Lembaga Studi Realino, 1996).
} 
Hal yang sama juga terjadi di Eropa atau Asia kuno, di mana Aristoteles menyebut pekerjaan pedagang/wira usaha sebagai semacam perampokan, karena usaha seperti itu seperti permainan habis-habisan (zero sum game): di mana yang satu memperoleh hasil, yang lain kehilangan. ${ }^{7}$ Pada jamanNya, Yesus juga mengingatkan agar para pedagang tidak memungut laba lebih dari seharusnya (Mrk. 11: 15-19; Yoh. 2: 13-16). Dalam beberapa hal, sebenarnya, sikap dan karakter Yesus memperlihatkan sikap seorang wirausaha, khususnya berkaitan dengan kreativitas, inovasi, dan kehendak untuk terus maju dan memperbaiki kehidupan. Mengapa kewirausahaan didefinisikan secara negatif? Sejak kapan kewirausahaan mempunyai momentum positif dan menjadi salah satu profesi atau pekerjaan yang sama dengan pekerjaan lain?

Pada masyarakat yang stratifikasi sosialnya terbelah: penguasa-rakyat, pemilik modal/ tanah-petani, posisi pelaku wira usaha/entrepreneur tidak dikenal. Kalaupun ada, penghargaan terhadapnya relatif rendah. Namun, seiring dengan perkembangan masyarakat, beberapa profesi baru bermunculan karena beberapa sebab dan kebutuhan. Demikian juga seturut kebutuhan tersebut, posisi wirausaha secara perlahan menempati posisi penting, khususnya dikaitkan dengan proses produksi dan distribusi barang dan/atau jasa.

Konteks Eropa dan Jawa/Indonesia tampaknya mempunyai beberapa kesamaan dengan munculnya kelompok baru ini: entrepreneur/pengusaha. ${ }^{8}$ Praag (1999) menelusuri istilah pengusaha dan menilainya secara baru berdasarkan tulisan Richard Cantillon, Jean-Baptista Say, Alfred Marshall, Joseph Schumpeter, Frank Knight, dan Isreal Kirzner. Sementara untuk konteks Jawa akan bersandar pada beberapa tulisan, seperti Koentjaraningrat (1988), Nakamura (2012), Realino (1996), Geertz (1998), dan Shiraishi (1997).

Cantillon (1680-1734), boleh jadi, menurut Praag (1999) merupakan penulis pertama yang memberi tempat secara layak dan positif definisi dan posisi pengusaha dalam konteks Eropa. Menurutnya, pengusaha mempunyai posisi antara pemilik tanah dan pekerja upahan. Atau, pengusaha adalah posisi perantara (broker, arbitrage[r]), yang bertugas dalam seluruh pertukaran (exchange) dan peredaran (circulation) ekonomi. Faktor pendorongnya adalah potensi keuntungan yang diperoleh dari membeli dengan harga tertentu dan menjual dengan harga yang (belum) tak tentu. Singkatnya, pengusaha berfungsi sebagai perantara, maka selain membutuhkan inovasi dan kreativitas, mereka juga bergelut dengan ketidakpastian.

Memperluas definisi Cantillon, Jean-Baptiste Say (1767-1832) menyatakan bahwa fungsi kreatif itulah yang menjadikan pengusaha dekat dengan kesejahteraan dan kekayaan (wealth). Menurutnya, ada tiga fungsi produksi dan industri yang berkaitan erat dengan pengusaha, yaitu: pengetahuan teoritis, aplikasi pengetahuan, dan penjabarannya (execution). Bagi Say, pengusaha merupakan tulang punggung sistem produksi, distribusi dan konsumsi. Dia merupakan koordinator dalam strata pasar dan strata perusahaan. ${ }^{9}$

\footnotetext{
${ }^{7}$ Praag, Some, 312.

${ }^{8}$ Untuk konteks Jawa (Indonesia) ada beberapa istilah yang sering digunakan untuk menunjuk kelompok ini: makelar (Koentjaraningrat 1990); walaupun dalam kelompok pedagang ini, Koentjaraningrat masih memisahkan antara bakul (pedagang kecil) atau pengecer (peddler); pedagang atau juragan (Nakamura 2012), atau sekarang pengusaha. Namun, untuk kepentingan tulisan ini akan digunakan istilah pengusaha/pelaku wira usaha, yang mungkin (dalam konteks Bahasa Indonesia) lebih dekat dengan entrepreneurship.

${ }^{9}$ Praag, Some, 316.
} 
Marshall dan Schumpeter kemudian memperluas makna dan posisi pengusaha dalam sistem ekonomi modern (neo-liberal). Untuk melukiskan betapa pentingnya fungsi pengusaha dalam sistem pasar, Schumpeter membangun teorinya demikian: "bayangkan dunia ini tanpa pengusaha, hidup menjadi "aliran berputar/tertutup" (circular flow). Semua akan terulang begitu saja setiap hari. Inilah dunia tanpa ketidakpastian dan perubahan". Lalu, ia melanjutkan, "seorang pengusaha kemudian hadir di panggung; dia memang ingin mencari untung. Ia lalu menghadirkan sebuah kombinasi baru atau inovasi untuk mencapai tujuannya." Penciptaan inovasi pengusaha inilah, yang oleh Schumpeter dinilai sebagai penyebab utama perubahan (pembangunan) dalam sistem ekonomi. ${ }^{10}$

Pendeknya, pengusaha adalah seorang pembaru dan pemimpin; keduanya sangat berkaitan erat dengan perubahan atau transformasi. Karena itu, kewirausahaan, bagi Schumpeter, juga berkaitan dengan kondisi seseorang, yang terus mampu menciptakan pembaruan dan memimpin pembaruan ke arah kemajuan ekonomi. Pada sisi lain, Kirzner membela pengusaha dengan mengatakan mencari keuntungan tidak selalu bersifat eksploitatif, tetapi berkaitan erat dengan inovasi, perubahan dan penciptaan: one 'can capture the associated profits by innovating, changing and creating'. Sekali lagi, seperti Schumpeter, kewirausahaan selalu terkait erat dengan kepemimpinan dan kreativitas: upaya selalu mencipta. ${ }^{11}$

Walau konteksnya sedikit berbeda, kewirausahaan di Jawa terkait erat dengan kemandirian dan kepeloporan. Pada pengusaha (besar dan kecil) Tionghoa dan Jawa, kita melihat aspek kemandirian dan kepeloporan lebih menonjol. Kedua sikap itu tampaknya tidak bisa dipisahkan dari karakter kewirausahaan secara umum, seperti kreativitas, inovasi, dan tentu saja kepemimpinan, yang ditujukan untuk diri sendiri dan masyarakat (pasar).

Pada masa revolusi dan perjuangan kemerdekaan, sulit dibayangkan jika para tokoh Islam tidak masuk dalam dunia pergerakan Indonesia. Sarekat Islam semula adalah Sarekat Dagang Islam. Sarekat Islam merupakan gambaran transformasi semangat kepeloporan dan kemandirian dalam bidang ekonomi yang berproses menjadi gerakan politik dan kebangsaan. ${ }^{12} \mathrm{Hal}$ ini juga terjadi di kalangan kelompok Tionghoa, yang tidak sekadar ingin dibatasi geraknya dalam bidang ekonomi, tetapi dengan kesadaran penuh dan mandiri, kelompok ini juga melakukan transformasi ke arah gerakan politik dan kebangsaan. ${ }^{13}$

Secara ringkas, konsep kewirausahaan di Eropa dan Jawa pada satu sisi mempunyai beberapa kemiripan dasar, tetapi ada juga faktor sejarah penting yang membedakannya. Faktor yang mungkin bisa ditarik secara bersama adalah: pada mulanya kewirausahaan adalah merupakan fungsi perantara di antara produsen dan konsumen, dan hal itu dilatarbelakangi oleh motif mencari untung; namun seiring dengan kompleksitas kehidupan dan masyarakat, kewirausahaan tidak selalu dikaitkan dengan ekonomi. Pada konteks Eropa hal itu dikaitkan dengan semangat memimpin dan menciptakan perubahan dalam masyarakat; sementara pada konteks Jawa hal itu dikaitkan dengan fungsi kepeloporan dan kemandirian. Kalau di Eropa

\footnotetext{
${ }^{10}$ Ibid., 320 .

${ }^{11}$ Ibid., 326.

${ }^{12}$ Shiraishi, Zaman Bergerak: Radikalisme Rakyat di Jawa 1912-1926 (Jakarta, Pustaka Grafiti Utama, 1997); Nakamura, The Crescent.

${ }^{13}$ Lohanda, Growing Pains: The Chinese and The Dutch in Colonial Java, 1890-1942 (Jakarta, Yayasan Cipta Loka Caraka, 2002), 171-195.
} 
perkembangan kewirausahaan tidak terkait dengan bidang politik secara langsung, di Jawa hal itu harus terkait.

\section{Kerja, Panggilan dan Kewirausahaan: Proses Sekularisasi}

Salah satu tradisi kepercayaan Kristen yang paling tua tentang pekerjaan, kemungkinan besar adalah apa yang dikerjakan dan diajarkan Paulus (1 Tes. 2: 9, 12; 2 Tes 3: 7, 10-11; 2 Kor. 11: 27; dan Kis. 18: 3; 20: 34). Kerja itu dikaitkan dengan pewartaan Injil (Rm. 16: 12; 1 Kor. 15: 10; 16: 16; 2 Kor. 8: 23; 1 Tes. 1: 5), kemandirian hidup (1 Tes 2: 9; 4: 11; 2 Tes. 3: 7, 10), peran dalam organisasi dan kepemimpinan (1 Tes. 5: 12; 2 Kor 8: 23); namun, kerja bisa sebagai kegiatan transitif (Rm. 4: 4), kerja sebagai kegiatan subyektif manusia (Kis. 20: 35; Rm. 16: 6; 2 Kor 1: 24; 11: 27; Ef. 4: 28; 1 Tes. 2: 9; 5: 12; 2 Tes. 3: 7, 10-11), dan dikaitkan dengan profesi tertentu (2 Tim. 2: 6). Melalui pesan-pesannya tersebut, Paulus berusaha tidak membedakan antara pekerjaan "untuk hidup" maupun "untuk Tuhan". Melayani Tuhan menjadi bagian dari pekerjaan hidup sehari-hari maupun sebaliknya.

Sayangnya, dalam perkembangan selanjutnya, pikiran Aristoteles memengaruhi dan mengubah hal itu. Pekerjaan lalu dibedakan menjadi dua: (1) pekerjaan yang berkaitan dengan pengetahuan, dilakukan oleh mereka yang punya banyak waktu luang; dan (2) pekerjaan yang cocok untuk para budak dan tenaga kasar, yang berkaitan dengan kerja fisik, "tangan dan kaki”. Kehormatan seseorang tidak ditentukan oleh pemilikan kekayaan material, karena itu perdagangan dan wirausaha digolongkan sebagai aktivitas yang "kotor", yang tidak selayaknya dilakukan oleh mereka yang mempunyai pendidikan (liberal-arts) atau budaya. ${ }^{14}$

Mengapa pekerjaan yang berkaitan dengan berdagang dianggap rendah? Bahkan, dalam konteks Perjanjian Baru pun, pekerjaan seperti ini dikaitkan dengan sikap mencuri dan mengambil untung dari orang lain dengan semena-mena. Setelah kekristenan bergeser dari wilayah pedesaan di masa Yesus ke wilayah perkotaan di masa Para Rasul, termasuk Paulus, konsep kerja dan kewirausahaan mulai mengalami sedikit pergerseran. Pada masa Yesus, di mana ekonomi bercorak subsisten dan berorientasi pada keluarga yang tertutup, peran wira usaha menjadi bagian yang tak terpisahkan dari kerja keluarga, sehingga perannya sangat kecil sekali atau diabaikan. Sementara, bagi Paulus yang hidup di wilayah perkotaan, kerja merupakan sarana untuk bertahan hidup (Kisah 18: 3), sekaligus sebagai cara membangun relasi dan metode pekabaran Injil. Paulus adalah pembuat dan pedagang tenda. Karena itu, kerja bagi Paulus bermakna ganda: pada satu sisi untuk kemandirian dan tidak menjadi beban orang lain (2 Kor 11: 9; 2 Tes 3: 8), pada sisi lain sebagai penopang pekabaran Injil.

Baru sesudah terjadi Revolusi Perancis yang merombak susunan masyarakat, konsep kerja juga mulai berubah. Pekerjaan yang melibatkan kreativitas, inovasi, dan "menjadi perantara" mulai memperoleh perhatian. Industri dan perdagangan pun mendukung munculnya profesi seperti itu, yang kemudian dikenal sebagai wira-usaha. Namun, benih-benih gagasan yang mendukung proses sekularisasi kerja sudah mulai terjadi di Jerman pada dekade sebelumnya: Luther telah menggunakan kata Beruf[ung] (panggilan) tidak hanya pada tugas-tugas kebiaraan, tetapi juga menunjuk pada occupation (pekerjaan), class (klas), dan office atau pela-

\footnotetext{
${ }^{14}$ Preece, Christianity and Entrepreneurship, Protestant dan Catholic Thoughts (New South Wales, The Center for Independent Studies, 1999), 16-17; Ancil, “A Humane Economy versus Economism” dalam Humanitas, vol XXV, No. 1 and 2, 2012, 66.
} 
yanan administrasi. ${ }^{15}$ Implikasi dari pemikiran Luther ini, setiap pekerjaan, termasuk bisnis, berharga di mata Allah. ${ }^{16}$

Sayangnya, memasuki abad ke-20, dengan semakin berkembangnya industrialisasi, nilai serakah dan materialisme telah ikut mengerogoti nilai-nilai baik wirausaha. Sehingga, telah terjadi pergeseran besar-besaran dari humane economy ke economism, di mana upaya wirausaha selalu dikaitkan dengan kebutuhan material, dan bukannya mempertemukan satu orang dengan orang lain; atau ukuran keberhasilan seseorang hanya dilihat dari kepemilikan material, ${ }^{17}$ sehingga memicu nafsu serakah. Akibatnya, wirausaha kurang diberi tempat dalam gereja. Wirausaha selalu dikaitkan dengan penipuan, mengambil hak orang lain, dan berbagai praktik "memperkaya diri" tanpa mempertimbangkan keadilan dan hidup bersama yang lebih baik. Kapitalisme, terutama yang berkembang pada awal abad ke-19, telah menggunakan dasar baru: "serakah adalah baik". ${ }^{18}$ Keserakahan menjadi "mesin" penggerak konsumsi materialistis, sehingga mendorong produksi, dan meningkatkan untung atau profit. Wirausaha yang semula untuk meningkatkan produktivitas dan kesejahteraan telah bergeser jauh menjadi mengejar keuntungan.

Karena itu, supaya wirausaha kembali menjadi alat yang memartabatkan manusia, diperlukan tinjauan ulang, baik dari sisi historis, teologis, dan biblis, supaya ditemukan makna barunya. Tanpa upaya demikian, wirausaha akan terus dicurigai oleh gereja sebagai salah satu penyebab dasar proses pemiskinan terhadap sebagian besar orang, khususnya mereka yang "kalah" dalam perlombaan mencari untung.

Perkembangan wirausaha di Indonesia, selama ini, memang tidak terpisah dari keberadaan kelompok Cina atau Tionghoa, Arab dan/atau Islam, ${ }^{19}$ yang sejauh bisa dilacak terkait dengan Sarekat (Dagang) Islam dan juga Gerakan Muhammadyah. ${ }^{20}$ Kelompok Tionghoa ini sejak sebelum Jaman Tanam Paksa selalu dijadikan "perantara" antara kelompok kolonial dengan inlander. Peran mereka bisa menjadi semacam penarik pajak, tetapi yang lebih luas adalah perang pedagang perantara. Mereka berperan menjadi semacam tengkulak yang menjadi penyalur produk pertanian dari petani (produsen) kepada perusahaan Belanda. Siasat ini memang membatasi Tionghoa tetapi sekaligus membuat ciri berbeda, yang menjadikan kelompok ini sedikit sulit melakukan praktik asimiliasi dengan penduduk lokal.

Sementara, dalam kelompok Islam, Sarekat Islam tumbuh seiring dengan dirombaknya sistem lungguh di dua kerajaan Islam di Jawa (Surakarta dan Yogyakarta). Usaha mereka semula merupakan upaya untuk membentuk klas tersendiri karena tiadanya akses terhadap lungguh. Mereka mengembangkan kerajian batik sebagai upaya untuk menanggapi perubahan

\footnotetext{
${ }^{15}$ Preece, Christianity, 20.

${ }^{16}$ Wijaya, Kesalehan Pasar: Kajian Teologis terhadap Isu-isu Ekonomi dan Bisnis di Indonesia (Jakarta, Grafika Kreasindo, 2010), 5-6.

${ }^{17}$ Ancil, A Humane.

${ }^{18}$ Lihat dalam, Meeks, God, The Economist: The Doctrine of God and Political Economy (Minneapolis, Fortress Press, 1989); Preece, Christianity, dan Roels, "The Christian Calling to Business Life" dalam Theology Today, 2003, 357-369.

${ }^{19}$ Baca, Ricklefs, Polarising Javanese Society: Islamic and Other Visions, c. 1830-1930 (Singapore, National University of Singapore Press, 2007).

${ }^{20}$ Bandingkan, Abdullah, "Perilaku Ekonomi Pedagang Batik: Kasus Malioboro, Yogyakarta" dalam Masyarakat Indonesia, vol. 16 (2), 1989, h. 213-229; Geertz, "Javanese Kijaji: The Changing Role of A Cultural Broker", dalam CSSH, II, 1959-1960, 228-249.
} 
kebijakan Belanda yang mulai memperkenalkan sistem pasar dalam industri perkebunan besar dengan menarik modal asing secara besar-besaran. Sehingga, kelompok ini merupakan kelompok yang "sadar" tentang perubahan, dan mulai melakukan tanggapan terhadap perubahan itu dengan melakukan kegiatan usaha memanfaatkan peluang yang ada, dan ternyata menghasilkan sebuah kelompok baru. Selain wira usaha batik dan kerajinan, karena tumbuh sebagai borjuasi yang sadar, mereka juga mulai merambah bidang baru: pers dan pemberitaan. $^{21}$

Muhammadiyah sebagai "simbol" kewirausahaan, semula lahir sebagai bentuk pemurnian praktik keagamaan Islam di Jawa yang dianggap sinkretis, ${ }^{22}$ yang ditempuh melalui pendidikan dan penyebaran agama secara murni. Berbeda dengan Sarekat Islam, yang jelas punya haluan politik, maupun Budi Utomo pendidikan, Muhammadiyah memang merupakan gerakan sosial-keagamaan. Namun begitu, gerakan ini pada praktiknya juga melakukan "perlawanan" terhadap Belanda dengan cara mendirikan sekolah dan kegiatan ekonomi lainnya guna mewujudkan kemandirian. Oleh sebab itu, tidak heran kalau di lokasi gerakan ini lahir, Kota Gede, muncul berbagai kelompok wirausaha yang luar biasa maju, dan menjadi salah satu pilar ekonomi Yogyakarta dari dulu hingga sekarang ini. Dari wilayah inilah lahir berbagai kreativitas yang menjadikan kota Yogya sebagai "kota budaya atau seni", yang mampu mengekspor berbagai kerajinan (batik, perak, bambu, peralatan dapur) ke berbagai kota di Indonesia.

Berbeda dengan Kristen yang dalam perjalanan sejarahnya telah menanggalkan aspek keagamaan dalam mengembangkan soal kerja dan wirausaha, Islam justru selalu mengaitkan bahwa kerja dan wirausaha harus menjadi bagian dari keyakinan dan merupakan mandat agama sebagai sarana siar. $^{23}$ Kelompok Tionghoa tampaknya pada awal juga selalu mengaitkan bisnis dengan keyakinan keagamaan, tetapi dalam era Orde Baru, bukan agama, melainkan praktik kolusi dan relasi dengan penguasa menjadi kunci penting dalam wirausaha.

\section{Kitab Suci dan Kewirausahaan: Pendekatan Apresiatif}

Bagian ini menggunakan pendekatan apresiatif terhadap kekayaan dan kewirausahaan. Walau kewirausahaan tidak selalu terkait dengan kekayaan, dalam hal ini keduanya akan dilihat sebagai padanan satu sama lain. Kewirausahaan di sini dilihat sebagai suatu upaya melakukan perubahan atau penciptaan kehidupan yang lebih baik, yang didasarkan pada semangat tertentu (misal keagamaan), yang mewujud dalam bentuk kreativitas, inovasi, dan bertujuan membangun kehidupan bersama yang lebih baik, yang mewujud dalam lembaga secara berkelanjutan.

Untuk melihat itu, ada dua bagian dalam Kitab Suci yang digunakan sebagai sarana melihat dan mempertautkan kewirausahaan dengan nilai keagamaan Kristen: (1) Kitab Kejadian, khususnya pasal 1-2; (2) Injil Matius dan Lukas, dan (3) Surat Korintus. Pendekatan apresiatif yang dimaksud dilakukan dengan memulai menjelaskan hal-hal yang menarik di antara kedua bagian Kitab Suci dengan gagasan kewirausahaan. Melalui pendekatan ini segala upaya yang bersifat kreatif dan produktif akan dilakukan. Sehingga, diharapkan akan dihasilkan sebuah

\footnotetext{
${ }^{21}$ Shiraishi, Zaman Bergerak.

${ }^{22}$ Nakamura, The Crescent, 53.

${ }^{23}$ Ibid., 183-196.
} 
"pertemuan" yang positif antara gagasan kewirausahaan dengan nilai-nilai Kitab Suci: penyelamatan, kesejahteraan, dan sejenisnya.

\section{Tuhan dan Mentalitas Kewirausahaan: Kitab Kejadian}

Apakah Alkitab mendukung bagi lahir dan tumbuhnya mentalitas kewirausahaan? Apakah Tuhan bisa menjadi model bagi pengembangan mentalitas kewirausahaan? Ronald Mawby dalam tulisannya, The Entrepreneurial God $^{24}$ mengembangkan gagasan Tuhan sebagai pengusaha/wirausaha. Namun, sekali lagi, konsep wirausaha di sini tidak melulu soal teknis sederhana mengenai menjalankan usaha, melainkan sebuah sebuah pilihan epistemik. Artinya, wirausaha adalah keputusan mempergunakan sumber daya sekarang ini untuk menciptakan masa depan yang belum pasti menjadi lebih baik. Karena itu, ketidakpastian membuat tindakan wirausaha mempunyai risiko. Inilah yang disebut Mawby sebagai situasi epistemis, yaitu situasi yang dialami oleh setiap orang yang mengambil atau memulai tindakan untuk masa depan yang belum pasti. $^{25}$

Mendasarkan pada Kitab Kejadian, Mawby menjelaskan bahwa Tuhan sebenarnya sedang menjalankan peran sebagai wirausahawan atau mempunyai mentalitas wirausaha. Karena, menurutnya, tindakan kewirausahaan merupakan pilihan epistemik...yang muncul dari berbagai alternatif asli (genuine), dan tindakan pilihan tersebut mempunyai kekuatan tetapi terbatas. Karena itu supaya membawa pengaruh, kekuatan lain perlu juga bekerja supaya menghasilkan "harapan bersama". Sementara, Sirico menjelaskan bahwa kewirausahaan adalah sebuah pranata yang "berdiri sendiri", tidak memerlukan intervensi pihak ketiga. Katanya, kewirausahaan adalah pranata yang berkembang secara organik dari intelektualitas manusia yang disituasikan dalam konteks tatanan alami kebebasan. ${ }^{26}$ Dengan talenta, panggilan, dan kemampuan ekonomis panggilan kewirausahaan diterapkan guna menghasilkan barang, jasa dan pekerjaan.

Kejadian 1: 1-2: 4 mengisahkan proses penciptaan alam semesta dengan segala isinya, termasuk manusia. Pada bagian ini kata yang paling perlu diberi perhatian adalah mencipta: mengadakan sesuatu yang baru, (Ibrani: bara). Kata ini mengandung makna "kegiatan kreatif illahi”. Menurut von Rad hal itu berarti: kerja sempurna tiada henti dan penciptaan dari ketiadaan (creatio ex nihilo), karena tidak dikaitkan dengan keberadaan material satupun. ${ }^{27}$ Lalu, mengapa proses penciptaan Tuhan dikaitkan dengan kata 'belum berbentuk', "tohuwabohu"? Ada yang menggabungkan kata ini, seperti von Rad, dan mengartikannya sebagai tanpa bentuk, dan sekaligus menjelaskan dasar kegelapan yang kacau secara material (chaos), yang boleh jadi mengancam seluruh ciptaan. Sementara Singgih memisahkan menjadi dua suku kata, tohu dan wabohu, dan mengartikan sebagai suasana padang belantara, tetapi juga sebagai material konkrit pra-penciptaan. ${ }^{28}$

\footnotetext{
${ }^{24}$ Ronald Mawby, “The Entrepreneurial God”, dalam The Midwest Quarterly (Vol. 43, No. 2, Winter 2002); materi ini diunduh oleh penulis pada 17 September 2013, dari http://www.questia.com/library/journal/1G1 82554368/the-entrepreneurial-god.

${ }^{25}$ Ronald Mawby, "The Entrepreneurial God", h. 227. Dia mengungkapkan demikian: "memisahkan sesuatu yang sudah mapan di masa silam, dan melompat ke masa depan yang dibayangkan".

${ }^{26}$ Sirico, "The Entrepreneurial Vocation” dalam Journal of Market and Morality, 3. No. 1, 2000, 7.

${ }^{27}$ Rad, Genesis: A Commentary (Philadelphia, Westminster Press, 1971), 47.

${ }^{28}$ Singgih, Dari Eden ke Babel: Sebuah Tafsiran Kejadian 1-11 (Yogyakarta, Kanisius, 2011), 40-41.
} 
Sama seperti Allah yang telah dengan kreatifnya berani berisiko, manusia yang telah diciptakan segambar denganNya juga mempunyai karakter yang sama. Karena itu, ketika manusia jatuh dalam dosa, dan menjalani hukuman seperti Promotheus, mereka tidak kehilangan semangat untuk bekerja dan menguasai bumi: memperbaruinya dan memodifikasinya. Dari situ bisa dinyatakan bahwa manusia memang diciptakan menjadi wirausaha, makluk wirausaha, walaupun telah jatuh dalam dosa. ${ }^{29}$

Bagian terakhir Kitab Kejadian, ayat 26-28, dikaitkan dengan tugas manusia, ada pertanyaan: apa arti ayat ini bagi tugas atau panggilan kewirausahaan manusia? Kata "memenuhi" bumi tidak mesti diterjemahkan dalam arti ada kekurangan, tetapi memperlihatkan kelimpahan ketika dunia/tanah dikerjakan dengan benar untuk memenuhi kebutuhan manusia; karena itu kata berkuasa menjadi penting, bukan dalam arti, bebas mengupayakannya tanpa batas. Berkuasa di sini bermakna retroaktif terhadap seluruh ciptaan yang lain: memberi relasi yang baru dengan Tuhan, dan Gerhard von Rad menyebutnya: "Tuhan bisa meminta tanggung jawab terhadap ciptaan lain melalui manusia". ${ }^{30}$ Dengan kata lain "diberi kekuasaan berarti harus bertanggung jawab"; sebab kekuasaan tanpa tanggung jawab tidak bermoral; karena itu supaya terjadi keseimbangan segi tanggung jawab mesti lebih besar daripada kekuasaan. ${ }^{31}$

Dengan demikian, sebuah wirausaha yang baik, berakarkan pada Kitab Suci, mempunyai dimensi etis dan bukan sekadar profit (untung). Mentalitas: kreativitas, inovasi, keberanian mengambil risiko, dan berusaha menjadikan hidup lebih baik, yang diperoleh dari Tuhan sendiri harus dipertanggungjawabkan secara etis-moral guna hidup bersama yang bijaksana dan baik, seperti Tuhan menciptakan Alam semesta. Dengan kata lain mentalitas wirausaha harus berorientasi kepada kesejahteraan bersama (melalui produksi, distribusi, dan transaksi) dan bukan keserakahan dan keuntungan pribadi.

\section{Keserakahan, Ketertutupan dan Kritik Yesus: Injil}

Pada bagian ini akan diperlihatkan dua hal mengenai kekayaan dan kewirausahaan. Bagian pertama adalah Matius 25: 14-30; dan kedua, Lukas 12: 13-21. Perumpamaan tentang talenta dikaitkan dengan Kerajaan Sorga mesti diinterpretasi secara bijaksana dengan mempertimbangkan konteks penulisan dan manfaatnya di masa kini. Kalimat pertama (versi BIS, LAI) demikian: "Sebab hal Kerajaan Sorga sama seperti seorang yang mau bepergian ke luar negeri, yang memanggil hamba-hambanya dan mempercayakan hartanya kepada mereka." Harus diakui pada saat itu, kegiatan ekonomi atau wirausaha tidak berkembang sepesat sekarang ini. Namun, kata mempercayakan harta, nanti akan disebut jelas: talenta, merupakan sesuatu yang penting untuk dipertimbangkan.

Talenta, dalam berbagai tafsiran, bisa diartikan dalam dua makna; pertama sebagai sejumlah uang tertentu; dan kedua sebagai anugerah yang diberikan Tuhan kepada setiap orang untuk dipergunakan dan dikembangkan: bisa berupa kemampuan alami dan berbagai hal lain yang kita miliki, seperti, kesehatan, pendidikan, harta milik, atau modal.

Di situ memang tidak dijelaskan ada perintah dari sang tuan. ${ }^{32}$ Hanya secara interpretatif, sang tuan memberi kebebasan kepada hamba-hambanya mengelola talenta yang diberikan.

\footnotetext{
${ }^{29}$ Preece, Christianity, 11.

${ }^{30} \mathrm{ad}$, Genesis, 58-59.

${ }^{31}$ Roels, "The Christian”, 359; Singgih, Dari Eden., 65-66.

${ }^{32}$ Menurut Injil Lukas, perintahnya jelas: berdagang. Boleh jadi, karena penulis Lukas memperhatikan konteks sosial-ekonomi, sehingga menulis kata berdagang sebagai kata penting.
} 
Apakah sang tuan menginginkan hartanya berkembang? Tidak cukup jelas diungkapkan dalam perikop ini. Hanya pada bagian akhir, kita tahu bahwa hamba yang tidak mengembangkan talentanya tidak diberi penghargaan. Dengan kata lain, malas, tidak bertanggung jawab, tidak kreatif dan produktif bukan tindakan terpuji di mata sang tuan. Sebaliknya, pengembangan, bertanggung jawab, terus kreatif memperoleh pujian. Pada sisi ini bukan hasil akhir yang ditekankan tetapi pada upaya mengembangkan diri, menanggung risiko dan bertanggung jawab yang menjadi penting. "Sang Tuan mengundang setiap hamba yang rajin untuk bersukacita bersamanya, karena mereka produktif “.33

Mengutip Kirzner, Sirico menegaskan bahwa kepekaan wirausaha memperlihatkan betapa pentingnya mengembangkan kemampuan alami kita, waktu kita, sumber daya kita dengan mengupayakan berbagai kesempatan baru dan terlibat dalam kegiatan yang mempunyai tujuan jelas. Dorongan wirausaha adalah untuk mencapai tujuan secara efisien, karena itu tujuan dan sarana harus jelas dirumuskan. ${ }^{34}$ Untung hanyalah salah satu alternatif dari kerugian. Oleh sebab itu, supaya tidak rugi harus dilakukan cara-cara kreatif untuk menggandakannya. Tuhan lebih menghargai yang menggandakan hasil, betapapun kecilnya, karena dengan itu memperlihatkan sisi tanggung jawab, sisi penatalayanan dengan tepat.

Melalui bagian ini kita juga perlu membedakan antara, pada satu pihak, kewajiban moral untuk menjadi kreatif dan inovatif dalam ekonomi, dan pada pihak lain, mempergunakan talenta dan sumber daya secara bijaksana. Oleh sebab itu, mengaitkan bagian ini dengan bagian sebelumnya, Kitab Kejadian akan memperlihatkan secara tegas bahwa konsekuensi dari manusia diciptakan segambar dengan Allah adalah kreatif, inovatif, bijaksana, bertanggung jawab demi kehidupan yang lebih baik.

Lukas 12: 13-21 $1^{35}$, menegaskan tentang kritik Yesus terhadap ketamakan/keserakahan, tetapi bukan kekayaan. Kritik Yesus ditujukan kepada orang muda ini karena ia menghimpun dananya untuk diri sendiri, dengan simbol memperluas gudangnya (Luk. 12: 18-19). Keserakahan dan ketamakan memisahkan satu orang dengan lain. Hal ini menjadikan dia beruntung sementara orang lain merasa dirugikan, memperoleh kelangkaan. Berkaitan dengan bagian ini, Meeks menyatakan "orang kaya tersebut tidak hanya mengancam orang lain, karena hidup menjadi sulit, tetapi juga mematikan hidupnya dengan menyimpan rapat-rapat kekayaanya. ${ }^{36}$

Mengapa Yesus mengritik tindakan menumpuk harta? Karena tujuan Tuhan adalah memenuhi semua kebutuhan manusia dan seluruh ciptaan secara cukup, dan karena itu kebenaran Tuhan menjadi utama (Band. Mat. 6: 11 dan Luk 12: 31). Keadilan jauh lebih penting daripada penumpukan kekayaan. Mengubah hidup untuk menjadi lebih baik dinilai berharga (dan ini bagian dari mentalitas kewirausahaan) daripada menumpuk dan melipatgandakan keuntungan. Tujuan hidup manusia bukan sekadar makan-minum dan menumpuk

\footnotetext{
${ }^{33}$ Preece, Christianity, 23; Sirico, "The Entrepreneurial Vocation”, 15.

${ }^{34}$ Sirico, "The Entrepreneurial Vocation", 16.

${ }^{35}$ Bagian ini memang tidak berkaitan langsung dengan kewirausahaan secara praktis. Namun, secara mentalitas bagian ini sangat dekat dengan kewirausahaan. Sebab, tujuan mulia kewirausahaan bukan sekadar penciptaan kekayaan (wealth creation) tetapi juga penyebarluasan kekayaan (wealth distribution). Karena itu, bagian ini diletakkan sebagai analisis kritis terhadap kewirausahaan dan keadilan.

${ }^{36}$ Meeks, God, The Economist, 175-176.
} 
kekayaan tetapi juga menghadirkan keadilan. Kewirausahaan jelas bertentangan dengan penumpukan keuntungan dan kekayaan.

\section{Kewirausahaan sebagai Jalan Tengah: Surat Paulus kepada Korintus}

Untuk melihat apakah kewirausahaan bisa masuk ke dalam panggilan Kristen, pertama-tama perlu meninjau konsep panggilan itu sendiri. Sudah disebutkan di atas bahwa konsep panggilan mengalami perubahan makna sesuai konteks jaman yang mempengaruhinya. Pada masa kekristenan awal, Paulus menafsirkan bahwa semua pekerjaan adalah panggilan; dan itu menunjukkan martabat manusia; karena itu dia menekankan pentingnya setiap orang bekerja dan mempertanggungjawabkannya kepada Tuhan.

Namun, untuk menjelaskan kaitan kerja, termasuk wira usaha sebagai (bagian penting) panggilan Allah, Paulus menghadapi situasi yang tidak mudah. Bahkan, karena pekerjaannya sebagai pembuat dan pedagang tenda, yang mempunyai relasi baik dengan beberapa keluarga dari golongan kaya di Korintus menjadi salah satu sebab munculnya ketegangan di jemaat yang dibangunnya.

Pada jemaat Korintus ini, Paulus tidak saja menghadapi perpecahan dalam kelompok (1 Kor 1: 10-12), tetapi juga kerasulannya diragukan (1 Kor 3: 5-7; 4: 1-5; 9: 1-3). Apakah pokok sengketa di Korintus? Dari sisi pengetahuan, sumber konflik adalah perbedaan pandangan tentang beberapa hal, seperti percabulan, penyembahan berhala, ketidakteraturan hidup, baik secara pribadi maupun dalam keluarga (1 Kor 6: 9-10). Namun, kalau dilihat secara sosial-ekonomi, konflik ini menggambarkan ketegangan antar-golongan ${ }^{37}$ : kayamiskin, terpelajar-bodoh, dan antar-etnis, baik Yahudi, Yunani dan jemaat lokal.

Secara aktual ketegangan itu melahirkan polarisasi: kelompok Paulus, Kelompok Apolos, (Kelompok Petrus, dan bahkan Kelompok Kristus); namun yang jelas sebenarnya adalah polarisasi antara kelompok Paulus dan kelompok Apolos (1 Kor 3: 4). ${ }^{38}$ Untuk itu, kita perlu melihat "kelompok Paulus" itu terdiri dari siapa saja, demikian juga "kelompok Apolos". Kalau memperhatikan surat Korintus ini, tampaknya beberapa keluarga terpandang dekat dengan Paulus, ${ }^{39}$ seperti, Krispus, Gayus, Stefanus, yang dibaptis oleh Paulus. ${ }^{40}$ Sementara, sudah ada beberapa nama sebelumnya, seperti Sostenes, yang akhirnya menjadi teman seperjalanannya (Kis. 18: 17), Akwila dan Priskila (keluarga Yahudi pendatang, Kis. 18: 2), ditambah Titus Yustus, dan Krispus, kepala rumah ibadat di Korintus (Kis. 18: 7-8), termasuk keluarga Kloe -yang memberi laporan.

Sementara, Apolos sendiri adalah seorang Yahudi yang berasal dari Aleksandria (Mesir), terpelajar, pandai berpidato, dan mempunyai pengetahuan sedikit tentang Kitab Suci, khususnya baptisan Yohanes (Kisah 18: 24-28). Dengan keberaniannya, dia bisa memperoleh tempat di jemaat Korintus. Boleh jadi, sebagain besar kelompok Yahudi di Korintus, yang meragukan jabatan rasul dalam diri Paulus, berpihak kepada Apolos.

\footnotetext{
${ }^{37}$ Lihat: Grant, Paul in the Roman World (Louisville, Westminster, John Knox Press, 2001).

${ }^{38}$ Dunn, 1 Corinthians (Sheffield, Sheffield Academic Press, 1997), 31, menjelaskan panjang lebar soal perpecahan dalam berbagai kelompok; pada akhir penjelasannya, tampaknya, dia juga berkesimpulan sebenarnya hanya terjadi polarisasi antara kelompok Paulus dan Apolos.

${ }^{39}$ Ibid., 47-48.

${ }^{40}$ Theissen, The Social Setting of Pauline Christianity: Essay on Corinth (Philadelphia: Fortress Press, 1982), 102; dan Theissen, "Social Stratification in the Corinthian Community: A Contribution to the Sociology of Early Hellenistic Christianity" dalam Theissen, Christianity at Corinth: The Quest for the Pauline Church (Louisville, Westminster, John Knox Press, 105.
} 
Memperhatikan latar belakang beberapa orang dekat Paulus, khususnya Akwila dan Priskila serta Krispus, merupakan orang-orang terpandang. Bisa diduga bahwa pendapatan mereka secara ekonomis tentu cukup atau malah berkelimpahan. Demikian juga Krispus, status sebagai kepala rumah ibadat tentu berakibat pada pendapatan yang diperolehnya. Bahkan, ketika Timotius dan Silas datang dari Makedonia, Paulus merasa bisa melakukan pekabaran Injil dengan baik, karena tidak disibukan dengan pekerjaan membuat tenda. Mereka telah membawa persediaan dana yang cukup untuk pelayanan pekabaran Injil (Kis. 18: 5).

Ditambah dengan berbagai perbedaan latar belakang budaya dan kebiasaan, kekristenan yang masih muda mengalami berbagai persoalan. Mereka yang dekat dengan kelompok kuat secara ekonomi menjadi sasaran tembak. Karena berkaitan dengan golongan dan pengikutnya, kasus Paulus lebih mirip konflik sosial-politik daripada pertentangan teologis. ${ }^{41}$ Paulus tampaknya terkena oleh situasi yang demikian. Lalu, muncullah berbagai persoalan yang semuanya ditujukan untuk menguji dirinya: apakah Paulus memang rasul Tuhan. Konflik yang dihadapi Paulus, tidak sekadar konflik tentang ajaran kekristenan, tetapi itu kemungkinan besar juga merefleksikan ketegangan dan jurang sosial ekonomi ${ }^{42}$ dalam jemaat Korintus yang masih muda.

Berkaitan dengan status kerasulannya, Paulus dengan sengaja memilih melakukan wirausaha sebagai jalan tengah bagi ketegangan akibat perbedaan sosial dalam jemaat (1 Kor. 9:15, 17-18): tidak menggunakan haknya untuk mendapat upah sebagai dasar pelayanan gereja. Mengapa itu dilakukan? Karena Paulus menghendaki kemandirian. Pasti tidak cukup mudah membagi waktu antara mengelola bisnis dan melakukan pelayanan. Dunn tampaknya lebih rasional bahwa walaupun Paulus menjalankan wira usaha, dia masih terbuka terhadap bantuan dan keterbukaan dari warga jemaat yang ada di Korintus, walau disadari olehnya sumber ketegangan itu juga berasal dari relasinya yang dekat dengan para teman yang membantunya. ${ }^{43}$

Terlepas dari itu semua, tampaknya kita perlu melihat kaitan wira usaha Paulus dengan panggilannya sebagai pekabar Injil. Berkaitan dengan panggilan, Paulus menjelaskan, seperti tertulis dalam I Korintus 7: 20. Bagian ini hendak menegaskan bahwa panggilan bukanlah terbatas pada pekerjaan yang berkaitan dengan tugas kerohanian saja; atau lebih ekstrim hanya terarah kepada pekerjaan, seperti, biarawan/biarawati yang menghindari tugas harian dan kekayaan. Paulus dalam bagian ini hendak menekankan bahwa panggilan dikaitkan dengan pertobatan dan posisi sosial atau profesi yang dijalaninya (I Kor. 7: 21-22). Dengan kata lain, pekerjaan apapun, kalau diletakkan dalam ketaatan kepada hukum Allah (ayat 19) dan untuk kebaikan bersama (dimulai dari jemaat dan meluas ke masyarakat), maka itu merupakan panggilan Allah.

Melihat kehidupan Paulus, kita bisa memperoleh beberapa hal yang penting untuk kita pikirkan mengenai kewirausahaan dan panggilan. Pertama, bisa jadi, pekabaran Injil Paulus di Korintus sebetulnya dilakukan sebagai bagian tak terpisahkan dari pekerjaannya sebagai pembuat dan pedagang tenda. Artinya, sembari membuka toko tenda, ketika menyambut pelanggannya, dia memberikan kesaksian tentang Injil Tuhan kepada semua orang, melalui

\footnotetext{
${ }^{41}$ Dunn, 1 Corinthians, 42-43.

${ }^{42}$ Grant, Paul, 25-27.

${ }^{43}$ Dunn, 1 Corinthians, h. 62-63.
} 
percakapan intensif. ${ }^{44}$ Kedua, dia membagi waktu antara pekerjaan menjual tenda dan melayankan pekabaran Injil. Hock dan Dunn menduga bahwa pada pagi sampai sore hari Paulus melakukan pekerjaan penjual tenda, dan pelayanan misi di sinagoge dilakukan pada malam hari. Pekerjaan membuat tenda sebagai bekal melakukan pekerjaan pekabaran Injil. Ketiga, Paulus memang membuka toko tenda. Tentu saja dia memerlukan beberapa orang tenaga pembantu dan pengelola. Dengan begitu, ketika saat tertentu melayani pekerjaan Injil, ia bisa meninggalkannya dan melakukan pengawasan terhadap tokonya secara berkala. ${ }^{45}$

Singkatnya, wira usaha Paulus bersifat konstruktif: untuk membangun harmoni di tengah konflik. Kewirausahaan Paulus merupakan konstruksi dan integrasi sosial, dan hal itu menjadi panggilan dia demi pengembangan dan pertumbuhan jemaat dan masyarakat.

\section{Merekonstruksi Kewirausahaan sebagai Panggilan yang Bertanggung Jawab}

Kewirausahaan, mendasarkan pada berbagai uraian di atas, tidak bisa dipersempit hanya kegiatan yang berkaitan dengan bisnis atau usaha ekonomi. Kewirausahaan sebetulnya muncul karena situsi kehidupan yang mandeg (Schumpeter), atau karena situasi kacau yang membutuhkan keputusan mendesak. Dalam situasi seperti itu, lalu mentalitas kewirausahaan menjadi sangat penting. Itulah sebabnya, Mawby dan Preece menyatakan sikap kewirausahaan tidak bisa dilepaskan dari sikap Tuhan sendiri ketika menciptakan alam semesta: kemandegan dan kekacauan.

Sebagai yang diturunkan dari sifat-sifat ilahi, maka di dalam manusia, dengan sendirinya, mempunyai mentalitas dan semangat kewirausahaan. Namun, sekali lagi, kewirausahaan ini tidak dalam arti teknis: memulai dan mengembangkan usaha ekonomi. Kalau dikaitkan dengan usaha ekonomi, memang tidak setiap orang mempunyai kemampuan dan keterampilan teknis-khusus di bidang itu; dan karena itu perlu pelatihan khusus. Artinya, dasar-dasar kewirausahaan ekonomis sudah ada dalam diri setiap orang, dan untuk mengembangkannya, sesuai dengan konteks, diperlukan pembiasaan yang sistematis. Singkat kata, setiap orang mempunyai kapasitas melakukan perubahan, karena di dalamnya dirinya sudah melekat "kewirausahaan ilahi”, seperti kerja keras, kreativitas, inovasi, mempertimbangkan risiko, dan berani mengambil risiko; dan semuanya dilakukan berdasarkan kesadaran (rasio) dan tanggung jawab (moral).

Dengan demikian, kalau ditarik lebih sempit, pelaku-pelaku usaha (dalam hal ini kewirausahaan ekonomis) tidak bisa melepaskan pekerjaannya, kecuali diakarkan pada makna wirausaha itu sendiri, yang berasal dari Allah. Karena itu, nilai-nilai dasar penciptaan, yang berkaitan dengan kewirausahaan, mesti menjadi pondasi bagi seluruh pelaksanaan kegiatan usaha ekonomi. Singkat kata, kewirausahaan ekonomis, tentu saja bisa mencanangkan pencarian profit atau untung sebagai tujuan, tetapi hal itu mesti dilakukan dengan nilai dasar, seperti ketika Allah mencipta alam semesta, yakni kesadaran untuk mengatasi kekacauan dan kemandegan dengan semangat kreatif, inovatif dan pantang menyerah, dan semuanya mesti terarah kepada masa depan yang lebih baik. Artinya, lebih sederhana lagi, keuntungan

\footnotetext{
${ }^{44}$ Bandingkan dengan Wijaya, Kesalehan, h. 99-102, yang menekankan, dengan mengutip Meeks, bahwa dimensi panggilan dalam pekerjaan adalah ketika pekerjaan itu mengandung pembebasan dan pemerdekaan martabat manusia; selain itu dengan menjadikan bisnis sebagai ladang panggilan dan pengembangan talenta, Wijaya menyatakan penolakannya terhadap pemisahan kehidupan spiritual dan kehidupan ekonomi.

${ }^{45}$ Hock, The Social Context of Paul's Ministry (Philadelphia, John Knox Press, 1980), h. 31-49.
} 
bukanlah orientasi usaha ekonomi, tetapi hal itu adalah "hasil tak langsung". Kalau dibuat dalam tiga urutan secara ideal, urutan pertama adalah kebaikan hidup (bersama dengan orang lain), kemudian penyelesaian masalah atau munculnya kesempatan atau alternatif baru, dan terakhir adalah keuntungan finansial. Kalau urutannya dibalik, dimulai dari yang terakhir, usaha ekonomi akan jatuh menjadi "sarana" menghancurkan kemanusiaan. Sebab, manusia lain hanya akan diambil uangnya. Inilah yang terjadi sejak jaman Yesus sampai sekarang ini, sehingga melahirkan kritik yang luar biasa tentang usaha ekonomi.

Untuk menjadikan kewirausahaan berdimensi kemanusiaan, diperlukan perubahan orientasi. Paling tidak ada tiga nilai penting dalam kewirausahaan supaya bisa menjadi panggilan hidup setiap orang: intellectus, res, dan opera atau kalau memakai diksi tiga G: God, good, dan governance, yang tujuannya adalah memproduksi barang dan jasa untuk meningkatkan dan memenuhi kemanusiaan manusia dalam masyarakat. ${ }^{46}$ Makna intellectus adalah wawasan kreatif dan inovatif yang merupakan anugerah dan harus terarah kepada Tuhan semata; opera menunjuk pada kemampuan mengelola dan mengoordinasikan, yang sekarang ini nilai utamanya adalah (good) governance, seperti efisiensi dan efektivitas, pertanggungjawaban, keterbukaan, cepat-tanggap, dan sejenisnya; dan res (sumber daya manusia dan modal yang produktif) guna menghasilkan good-ness bagi semua orang dan masyarakat. Tujuan dari semua itu adalah, meminjam istilah Paus Yohanes Paulus II: "mengorganisasi usaha-usaha produktif, merencanakan jangka waktunya, memastikan bahwa semua itu berkaitan dengan usaha positif memenuhi tuntutan yang memuaskan dan memper-hitungkan risiko, yang semuanya bersumber pada kesejahteraan masyarakat sekarang ini."

Lebih lanjut, mengapa harus good? Good atau baik di sini tidak sekadar kategori praktis. Baik di sini mesti memuat nilai ekonomis dan etis. Artinya, baik secara ekonomis adalah yang memungkinkan terjadinya perputaran roda ekonomi secara berkelanjutan; sedangkan baik secara etis, hal ini mesti dikaitkan dengan nilai keagamaan atau budaya secara umum, yaitu bahwa Allah menciptakan alam semesta dalam kondisi saling terbuka dan saling tergantung satu sama lain, sehingga diperlukan sikap saling bertanggung jawab. Kewirausahaan yang baik dan bertanggung jawab tidak bisa mengabaikan kehidupan orang lain dan alam semesta; justru sebaliknya ia harus mempertimbangkan hal ini dalam segala kegiatannya.

Sementara governance harus memuat aspek teknis dan estetis. Good governance adalah perangkat manajemen-teknis untuk melihat apakah sebuah institusi menerapkan sebuah pelayanan yang berorientasi kepada masyarakat atau tidak. Hal ini bisa dilihat dari dua sisi sekaligus, sisi pemberi layanan dan penerima layanan. Nilai yang hendak diperlihatkan di sini adalah bahwa tidak ada pelayanan yang tidak bisa dipertanggungjawabkan. Karena itu keterbukaan, pertanggungjawaban, kecepat-tanggapan menjadi nilai-nilai penting. Kewirausahaan mestinya juga bisa mengacu kepada hal tersebut, sehingga tidak terjadi penyimpangan antara satu pihak dengan pihak lain (produsen dan konsumen, atau pihak-pihak yang menjembatani relasi kedua pihak tersebut).

Sedangkan berorientasi kepada God, artinya, kalau semua hal itu diterapkan dengan baik, tidak diragukan lagi, kewirausahaan atau para pelaku wirausaha bisa menjadi bagian dari

\footnotetext{
${ }^{46}$ Toth, "The Entrepreneurial Calling: Perspective from Rahner and Lonergan" (Pennsylvania, n.a. 2019); Lihat juga, Yohanes Paulus II, Sollicitudo Rei Socialis, Ensiklik dalam rangka Ulang Tahun ke-20 "Populorum Progressio", 30 Desember 1987, yang diterjemahkan menjadi "Keprihatinan Akan Masalah Sosial” oleh P. Turan, Pr, Departemen Dokumentasi dan Penerangan KWI.
} 
"penyelenggaraan" Tuhan memelihara dunia. Dunia tidak diharapkan mandeg dan kacau, tetapi selalu bertumbuh dan berkembang menuju kebaikan untuk hidup bersama semua makluk di jagad raya. Salah satu unsur penting itu adalah kewirausahaan, sebagai upaya mendorong semua hal bergerak. Namun, pergerakan dan pertumbuhan itu tetap harus mengarah kepada kebaikan. Salah satu dimensi ilahi kewirausahaan adalah bertanggung jawab. Maka, dengan dimensi itu, sudah selayaknya, kewirausahaan bisa dipertimbangkan secara cermat menjadi bagian penting dalam panggilan kehidupan orang Kristen.

\section{Kesimpulan}

Sudah selayaknya pekerjaan wira usaha juga bisa dipertimbangkan sebagai panggilan Kristen. Namun, sebelum sampai pada hal itu, kita mesti melihat makna wira usaha secara jernih. Setiap wira usaha yang didasarkan pada intellectus yang berpusat pada Tuhan, yang dijalankan dalam opera yang berdasarkan good governance, dan semuanya untuk menghasilkan keadilan bagi setiap tenaga kerja, dan kebaikan bagi kehidupan bersama, bisa mulai dipertimbangkan dengan sungguh-sungguh sebagai panggilan Kristen. Sehingga, dengan begitu, banyak wira usaha yang akan menggali inspirasi dan aspirasi dari gereja. Kalau itu terjadi, wira usaha bukan saja akan menjadi "pekerjaan” yang "diteguhkan” gereja, tetapi juga mendorong gereja menjadi lebih terbuka, berkembang, dengan semangat melayani. Dengan begitu, gereja akan berkembang sebagai gereja yang manusiawi sekaligus ilahi: tidak mampu memprediksi masa depan dengan pasti, tetapi diberi kekuatan oleh Tuhan sendiri untuk memperbaiki diri berdasarkan keyakinan dan potensi diri yang dimilikinya.

\section{Referensi}

Abdullah, Irwan. "Perilaku Ekonomi Pedagang Batik: Kasus Malioboro, Yogyakarta." Masyarakat Indonesia 16 (2), 1989: 213-229.

Adi, Suwarto. "Religious Entrepreneurship: Christianity and Social Transformation in Contemporary Indonesia." Exchange 46. 4, 2017: 328-349.

Ancil, R. E. "A Humane Economy versus Economism." Humanitas, vol XXV, No. 1 and 2, 2012: 66-78.

Dunn, James D. G. 1 Corinthians. Sheffield: Sheffield Academic Press, 1997.

Geertz, Clifford. "Javanese Kijaji: The Changing Role of A Cultural Broker." CSSH, II, 19591960: 228-249.

-. Penjaja dan Raja: Perubahan Sosial dan Modernisasi Ekonomi di Dua Kota Indonesia. Jakarta: Yayasan Obor Indonesia, 1998.

Grant, Robert M. Paul in the Roman World. Lousville, Westminster: John Knox Press, 2001. Hock, Ronald F. The Social Context of Paul's Ministry. Philadelphia: Fortress Press, 1980. Koentjaraningrat. Javanese Culture. Singapore: Oxford University Press, 1990.

Kwartanada, Didi. "Minoritas Tionghoa dan Fasisme Jepang: Jawa, 1942-1945.” Dalam

Penguasa Ekonomi dan Siasat Pengusaha Tionghoa, oleh Lembaga Studi Realino, 24-42.

Yogyakarta: Kanisius dan Lembaga Studi Realino, 1996.

Lohanda, Mona. Growing Pains: The Chinese and The Dutch in Colonial Java, 1890-1942.

Jakarta : Yayasan Cipta Loka Caraka, 2002.

Mackenzie, A. Faith at Work: Vocation, the Theology of Work and the Pastoral Implications.

New Zealand: The University of Otago, 1997.

Mawby, R. "The Entrepreneurial God." Midwest Quarterly, Vol. 43, No. 2, Winter, 2002: 225-243.

Meeks, M. Douglas. God The Economist: The Doctrine of God and Political Economy.

Minneapolis: Fortress Press, 1989. 
Nakamura, Mitsuo. The Crescent Arises over the Banyan Tree: A Study of the Muhammadiyah Movement in Central Javanese Town, c. 1910s-2010. Singapore: ISEAS, 2012.

Praag, C. M. "Some Classis Views on Entrepreneurship.” De Economis, 147 (3), 1999: 311335.

Preece, S. G. Christianity and Entrepreneurship, Protestant dan Catholic Thoughts. New South Wales: The Center for Independent Studies, 1999.

Rad, Gerhard von. Genesis: A Commentary. Philadelphia: The Westminster Press, 1971. Realino. Penguasa Ekonomi dan Siasat Pengusaha Tionghoa. Yogyakarta: Kanisius dan Lembaga Studi Realino, 1996.

Ricklefs, M. C. Polarising Javanese Society: Islamic and Other Visions (c. 1830-1930). Singapore: National University Press, 2007.

Roels, S. J. "The Christian Calling to Business Life." Theology Today, 2003: 357-369.

Sharon Alvarez, Rajshree Agarwal, dan Olav Sorenson. Handbook of Entrepreneurship Research: Interdisciplinary Perpectives. New York: Springer, 2005.

Shiraishi, Takashi. Zaman Bergerak: Radikalisme Rakyat di Jawa 1912-1926. Jakarta: Pustaka Utama Grafiti, 1997.

Singgih, Emmanuel G. Dari Eden ke Babel: Sebuah Tafsiran Kejadian 1-11. Yogyakarta: Kanisius, 2011.

Sirico, R. A. "The Entrepreneurial Vocation." Journal of Market and Morality, 3. No. 1, 2000: 1-21.

Theissen, Gerd. "Social Stratication in the Corinthian Community: A Contribution to the Sociology of Early Hellenistic Christianity." Dalam Christianity at Corinth: The Quest for the Pauline Church, oleh Gerd Theissen, 97-106. Louisville, Westminster: John Knox Press, 2004.

- The Social Setting of Pauline Christianity: Essay on Corinth. Philadelphia: Fortress Press, 1982.

Toth, Richard M. Liddy and Willian J. The Entrepreneurial Calling: Perspective from Rahner and Lonergan. Pennsylvania, 19 September 2019.

Wijaya, Yahya. Kesalehan Pasar: Kajian Teologis terhadap Isu-isu Ekonomi dan Bisnis di Indonesia. Jakarta: Grafika Kreasindo, 2010. 